九州大学学術情報リポジトリ

Kyushu University Institutional Repository

\title{
The Socio-Economic Analysis of Extensive Turkey Production in Turkey
}

Tan, Sibel

Agricultural Economics Research Institute of Turkey, Ankara

Kai, Satoshi

Laboratory of Agricultural Marketing, Division of Industrial Organization of

Agribusiness, Department of Agricultural and Resoruce Economics, Faculty of Agriculture, Kyushu University

Dellal, I lkay

Agricultural Economics Research Institute of Turkey, Ankara

Tan, Sami

Department of Economics, University of Dokuz Eylul

https://doi.org/10.5109/4612

出版情報：九州大学大学院農学研究院紀要. 49 (2)，pp.525-532，2004-10-01. Faculty of Agriculture, Kyushu University

バージョン:

権利関係： 
J. Fac. Agr., Kyushu Univ., 49 (2), 525-532 (2004)

\title{
The Socio-Economic Analysis of Extensive Turkey Production in Turkey
}

\author{
Sibel TAN ${ }^{1}$, Satoshi KAI*, Ilkay DELLAL ${ }^{1}$ and Sami TAN ${ }^{2}$ \\ Laboratory of Agricultural Marketing, Division of Industrial Organization of Agribusiness, \\ Department of Agricultural and Resource Economics, Faculty of Agriculture, \\ Kyushu University, Fukuoka 812-8581, Japan \\ (Received April 9, 2004 and accepted July 13, 2004)
}

\begin{abstract}
There are two types of turkey breeding systems in Turkey. One is vertical integration with intensive raising, the other is conventional system with extensive way. In the conventional system mostly low income small family farms raise turkey for new year celebration and this agricultural activity is very important for these kind of farms in rural areas. The extensive turkey production system in Turkey are, mainly, made by small family farms to meet turkey consumption in the new year celebrations. In this study it was tried to determine socio-economic characteristics of these kind of farms. According to research results, average number of turkey in feeding is 843 heads, feeding period lasts about 8-9 months until the new year, $53.33 \%$ of farms slaughter turkeys their own places and sell the rest as live. Turkeys reach to $7.26 \mathrm{~kg}$ post feeding period. While variable costs constitute $86.26 \%$ of total production costs of turkey breeding, fixed costs constitute $13.74 \%$ of them. The highest share in total costs belong to feed costs $(47.23 \%)$ Finished weight of turkey is $7.26 \mathrm{~kg}$ and total live weight per farm is $3630 \mathrm{~kg}$. $1 \mathrm{~kg}$ live turkey cost is $0.8939 \$ / \mathrm{kg}$, Net income is $2702 \$$ and this net income from this production branch cover $61,41 \%$ of sufficient income for families in Turkey that is $4400 \$$.
\end{abstract}

\section{INTRODUCTION}

According to the 2001 statistics, there are 4 million agricultural farms, and animal and plant production are taken place on $75 \%$ of these agricultural farms in Turkey. The size of agricultural land on agricultural farms is 5 hectares on the average (SIS, 2002).

Depending on globalization process in the recent years, negative changes have occurred in the Turkish economy. Agricultural farms in rural areas have also been affected due to negative changes. As a result of economic power losses of some agricultural farms and migration of young population, especially, on small family farms, meet an important part of labor force need, because of such factors as marrying, finding a good job, education etc., agricultural farms, fully or partly, stop their production and migrate to towns and/or metropolitan cities.

In the world, especially in developing countries, different projects have developed to improve economic and social structures of households in rural areas and render sustainability. For the purpose of this aim, some projects have been developed by government in Turkey in recent years such as "Rural-urban" and "Come Back-to-rural". However, animal and plant production have been carried out in extensive manner but sustainability

\footnotetext{
1 Agricultural Economics Research Institute of Turkey, Ankara

2 Department of Economics, University of Dokuz Eylul, Izmir

* Corresponding Author (E-mail: satokai@agr.kyushu-u.ac.jp)
} 
level on agricultural farms in different regions. In addition, since these farms use cheep input and produce for certain markets, especially for local markets, they remain their existence in spite of insufficient income. One of the this production systems is extensive turkey breeding and on the contrary intensive production, turkey breeding in this system is carried out to meet turkey consumption for the celebration at the end of the year. In this system, turkeys, in the day time, graze in pastures, stubble, and/or fallow land during feeding for 8-9 months, have taken in poultry houses in the evenings.

The aim of this study is to determine socio-economic characteristics of farms engaged with extensive turkey breeding in Turkey and to search solutions about what could have been done to increase their revenues in these kind of small scale, mixed but mostly engaged with extensive farms.

\section{MATERIAL AND METHOD}

\section{Sampling and Data Collection}

Research has been conducted in Koceli and Tekirdag provinces. Because extensive turkey breeding is mostly done in these two cities of Turkey. All turkey breeding farms in 15 villages of these two cities constitute main population. Later, 62 turkey breeding farms were selected by random sampling. Primary data were obtained by face to face surveys. Data related to breeding, sociological and economic characteristics were obtained by questionnaire. Secondary data were obtained from the State Statistics Institute (SSI), State Planning Organization (SPO) and Ministry of Agriculture and Rural Affairs (MARA) of Turkey.

\section{Criteria of Socio-Economic Analysis}

Man labor unit was used for labor force calculation on studied farms. Population on farms regarding to capability converted to man labor unit in respect of age and gender. In economic analysis of farms, Gross Production Value (GPV), Gross Income (GI) and Net Income (NI) were calculated. GPV was obtained by multiplying total live weight obtained from production activity with product price. Costs incurred for production were calculated as fixed and variable costs. Total costs obtained by adding fixed costs to variable costs. GI was obtained by subtracting variable costs from GPV and NI was obtained by subtracting total production costs from GPV.

\section{RESULTS AND DISCUSSION}

\section{Structural and Breeding Characteristics of Farms}

As race, American Bronze is used for extensive turkey breeding in Turkey (Aksoy, 1996; Aksoy et al., 1996a, b). Farmers purchase turkey chicks from State Production Stations. Chick purchasing period is, generally, between 15 April-15 May. Chicks stay in rearing poultry houses approximately 2 months. After this period, goslings graze in pasture, stubble, and fallow land. During grazing period intensive feed are not given. Feeding period lasts about 8-9 months until the new year. $53.33 \%$ of studied farms slaughter turkeys their own places and sell the rest as live. Number of turkey in feeding is 843 heads. Turkeys reach to $7.26 \mathrm{~kg}$ post feeding period. $53.33 \%$ of farms state problems 
Table 1. Structural and Breeding Characteristics of Farms.

\begin{tabular}{ll}
\hline Turkey race & American bronze \\
\hline Chick buying & government \\
Chick buying period (month) & 15 April-15 May \\
Chick staying period in Poultry house (month) & 15 April/15 May-15 June \\
Feeding period (month) & 15 June-31 December (8Months) \\
Live weight post feeding (kg) & 7.26 \\
Turkey marketing & - Live \\
& - slaughtered \\
Marketing difficulty & Yes-53.33\% \\
& No-46.67\% \\
Information on breeding & Parents- $76.67 \%$ \\
& Production station-10.00\% \\
Turkey number breed in one year (head) & Other $13.33 \%$ \\
Engagement period in turkey breeding & 843 \\
\hline
\end{tabular}

related to marketing post feeding period while $46.37 \%$ of farms do not. Occupation period in extensive turkey breeding of farms is 24.27 years. Farmers on the most of the farms $(76.67 \%)$ stated that they obtained information on breeding from their parents (Table 1).

\section{Sociological Characteristics of Farms}

As shown on Table 2., average number of people on turkey breeding farms is 5.36. The share of individuals aged 15-49, constitute active population, in total number of individuals in family is $57.28 \%$. In the calculation of family labor force on farms, population converted to man labor unit in respect of age and gender. According to this, average man labor unit (MLU) on turkey breeding farms is 3.81 and individuals aged 15-49 constitute $70.32 \%$ of this rate. Therefore, young labor force got in family is at sufficient level.

Table 2. Distribution of Population as to Age Groups and Gender.

\begin{tabular}{|c|c|c|c|c|c|c|c|c|}
\hline \multirow{2}{*}{$\begin{array}{c}\text { Age } \\
\text { Groups }\end{array}$} & \multicolumn{4}{|c|}{ Population } & \multicolumn{4}{|c|}{ Labor force (MLU) ${ }^{1}$} \\
\hline & $\mathrm{M}$ & $\mathrm{W}$ & $\mathrm{T}$ & $\%$ & $\mathrm{M}$ & $\mathrm{W}$ & $\mathrm{T}$ & $\%$ \\
\hline $0-6$ & 0.33 & 0.2 & 0.53 & 9.89 & - & - & - & - \\
\hline $7-14$ & 0.4 & 0.43 & 0.83 & 15.49 & 0.30 & 0.22 & 0.52 & 13.53 \\
\hline $15-49$ & 1.5 & 1.57 & 3.07 & 57.28 & 1.50 & 1.18 & 2.68 & 70.32 \\
\hline $50-+$ & 0.6 & 0.33 & 0.93 & 17.34 & 0.45 & 0.17 & 0.62 & 16.15 \\
\hline Total & 2.83 & 2.53 & 5.36 & 100.00 & 2.25 & 1.56 & 3.81 & 100.00 \\
\hline
\end{tabular}

1 Coefficients used for converting to MLU for Men and Women aged 7-14,15-49, 50+ are, respectively, $0.5,1.0$ ( 0.75 for Women) and 0.75 ( 0.50 for women).

\section{Education Status}

Education level of individuals aged 7 and up is shown on Table 3. According to Table 3 , the share of illiterate individuals in families is $8.57 \%$ whereas the rate of literate individuals is $91.43 \%$. The rate of literate individuals in respect of gender is $91.30 \%$ for 
Table 3. Educational Status.

\begin{tabular}{lccccccc}
\hline & Illiterate & Literate & $\begin{array}{c}\text { Primary } \\
\text { school }\end{array}$ & $\begin{array}{c}\text { Secondary } \\
\text { school }\end{array}$ & $\begin{array}{c}\text { High } \\
\text { school }\end{array}$ & University & Total \\
\hline Man & 8.70 & 4.35 & 71.01 & 7.24 & 8.7 & - & 100.00 \\
Woman & 8.45 & 4.23 & 71.83 & 8.45 & 4.23 & 2.81 & 100.00 \\
Total & 8.57 & 4.29 & 71.43 & 7.86 & 6.42 & 1.43 & 100.00 \\
\hline
\end{tabular}

men and $91.55 \%$ for women. Number of primary school graduates is higher than others and number of primary school graduates for men and women is $71.01 \%$ and 71.83 , respectively. This situation reveals that important part of families have a low level of opportunity getting another profession and agricultural production is their main living source (SIS, 2001).

\section{Other Sociological Characteristics of Farms}

All farmers are married. Education period is on the average 4.83. While the rate of watching TV and radio is over $95 \%$, the rate of watching agricultural programs is $73.33 \%$. The rate of regular newspaper reading is $36.67 \%$.

Table 4. Other Sociological Characteristics of Farms.

\begin{tabular}{lc}
\hline Marital Status & All Married \\
\hline Average Age (year) & 48.37 \\
Average Education Period (year) & 4.83 \\
Radio and TV watching rate & 96.67 \\
Agricultural Programs Watching Rate & 73.33 \\
Regular Newspaper Reading Rate & 36.67 \\
\hline
\end{tabular}

\section{Organizational Level}

Organizational level on farms is quite high. $80 \%$ of farms organized at cooperative level and 66.67 of farms organized at union level. In addition, there is no farm nonmember of any association. In spite of high organizational level, service is, mainly, provided for plant production. Farms are not member of any organization for turkey breeding.

Table 5. Organizational Status.

\begin{tabular}{lc}
\hline Organization Type & $\%$ \\
\hline Cooperative & 80.00 \\
Union & 66.67 \\
Association & 0 \\
\hline
\end{tabular}

\section{Working Status with Banks}

The rate of farms not working with banks is quite high (66.67\%). However, $33.33 \%$ of farms has commercial relation with bank especially for credit provision. 
Table 6. Working Status with Banks.

\begin{tabular}{lr}
\hline Farms & \multicolumn{1}{c}{$\%$} \\
\hline Working with banks & 33.33 \\
Not working with banks & 66.67 \\
Total & 100.00 \\
\hline
\end{tabular}

\section{Economic Characteristics of Farms}

\section{Land and Possession Type}

Plant production is also carried out on turkey breeding farms. As shown on Table 7., average land area of farms is 6.51 hectares. $94.88 \%$ of farm land is under farm property while $5.12 \%$ of that is under farm possession with leasing and sharecropping method. All farm land is arable land. Average parcel number is 8.85 .

Table 7. Land and Possession Type.

\begin{tabular}{llrc}
\hline Possesion Type & Land type & Da & $\%$ \\
\hline \multirow{2}{*}{ Property land } & Arable field & 61.77 & \\
& Arid & 54.77 & 94.88 \\
& Watery & 7.00 & \\
Sharecropping and leasing & Arable field & 3.33 & \\
& Arid & 2.33 & 5.12 \\
& Watery & 1.00 & \\
Farm land & Arable field & 65.10 & \\
& Arid & 57.10 & 100.00 \\
Average parcel number & Watery & 8.00 & \\
& & & 8.85 \\
\hline
\end{tabular}

\section{Crop Pattern}

Results show that farms intensify on grain production. Wheat, sunflower, corn, barley and oats production are done on $40.50 \%, 21.70 \%, 8.92 \%, 5.89 \%$ and $2.82 \%$ of farm land respectively. Average following land area is 11.71 decares, and constitute $18 \%$ of farm land.

Table 8. Crop Pattern.

\begin{tabular}{lcr}
\hline Products & Sowing area (da) & $\%$ \\
\hline Wheat & 26.27 & 40.50 \\
Barley & 3.83 & 5.89 \\
Oats & 1.83 & 2.82 \\
Sunflower & 14.13 & 21.70 \\
Corn & 5.40 & 8.29 \\
Other & 1.83 & 2.81 \\
Following land & 11.71 & 17.99 \\
Arable field & 65.10 & 100.00 \\
\hline
\end{tabular}




\section{Types and Distribution of Farm Animals}

Average turkey number on farms was 843 heads in the studied farms (see Table 9). There is no animal activity on $6.67 \%$ of farms except turkey production. However, Dairy cattle breeding and sheep and goats breeding are, respectively, carried out on $31.62 \%$ and $68.38 \%$ of farms. Dairy cattle and small ruminant numbers are 5.23 and 11.33 per farm respectively. High number of sheep and goats against cattle show that pastures in the areas of farms are more suitable for sheep and goats.

Table 9. Types and Distribution of Farm Animals.

\begin{tabular}{lc}
\hline Types of farm animals & head \\
\hline Turkey & 843 \\
Cattle & 5.23 \\
Cow & 1.97 \\
heifer & 1.13 \\
Calf & 1.03 \\
Calf milked & 1.03 \\
Bullock & 0.07 \\
Sheep and goats & 11.33 \\
Total & 16.57 \\
\hline
\end{tabular}

\section{Agricultural Equipment}

As shown on Table 10, average tractor number on farms is 0.70 . There is tractor on only $30 \%$ of farms. Farms having other agricultural equipment except tractor are at sufficient level. This stems from arable field agriculture of farms.

Table 10. Agricultural Equipment.

\begin{tabular}{lc}
\hline Agricultural equipment & number \\
\hline Tractor & 0.70 \\
Drill & 0.47 \\
Trailer & 0.70 \\
Plough & 0.53 \\
Pulverizator & 0.23 \\
Rake & 0.57 \\
Fertilizer distributor & 0.17 \\
\hline
\end{tabular}

\section{Costs of Turkey Breeding and Annual Revenue Status}

As seen on Table 11, while variable costs constitute $86.26 \%$ of total production costs of turkey breeding, fixed costs constitute $13.74 \%$ of total production costs of turkey breeding. The highest share in total costs belong to feed costs (47.23\%) and chick costs with $16.97 \%$, veterinarian-medicine costs with $9.56 \%$, permanent workmanship costs with 7.64 and seasonal workmanship costs with $4.13 \%$ follow feed costs. Post breeding live turkey weight is $7.26 \mathrm{~kg}$ and live weight per farm is $3630 \mathrm{~kg}$. $1 \mathrm{~kg}$ live turkey cost is $0.8939 \$ / \mathrm{kg}$. Gross Production Value (GPV) is $6840.83 \$$, Net Income (NI) is $2702 \$$ Gross Income is $3270.81 \$$. 
Table 11. Costs and Annual Revenues of Farms.

\begin{tabular}{|c|c|c|}
\hline Costs & $\begin{array}{c}\text { Value } \\
\$\end{array}$ & $\begin{array}{c}\text { Percentage } \\
\% \\
\end{array}$ \\
\hline \multicolumn{3}{|l|}{ 1. Pre-Production costs } \\
\hline - Disinfection (etalon) (quantity*price) & 13.72 & 0.33 \\
\hline$-\operatorname{Pad}(\mathrm{kg} * \$ / \mathrm{Kg})$ & 32.56 & 0.79 \\
\hline - Lime & 5.37 & 0.13 \\
\hline 2. Chick (number $* \$ /$ number) & 702.53 & 16.97 \\
\hline 3. Feed & 1954.89 & 47.23 \\
\hline 4. Temporary labor (hour* $\$ /$ hour) & 171.03 & 4.13 \\
\hline 5. Water $\left(m 3^{*} \${ }^{*} \mathrm{~m} 3\right)$ & 25.06 & 0.61 \\
\hline 6. Veterinery-Medicine & 395.61 & 9.56 \\
\hline 7. Heating & 94.88 & 2.29 \\
\hline 8. Illumination ( $\mathrm{kw} \mathrm{x} \$ / \mathrm{kw})$ & 35.56 & 0.86 \\
\hline 9. Other & 65.14 & 1.57 \\
\hline \multicolumn{3}{|l|}{ 10. Interest of variable costs } \\
\hline (variable costs $/ 2 * \mathrm{r} \%$ ) & 87.41 & 2.11 \\
\hline 12. Total Variable Costs (A) & 3570.02 & 86.26 \\
\hline 13. General management costs (Ax \%3) & 107.51 & 2.60 \\
\hline 14. Permanent labor & 316.39 & 7.64 \\
\hline \multicolumn{3}{|l|}{ 15. Depreciation of poultry house : } \\
\hline (poultry hose value*depreciation rate) & 66.28 & 1.60 \\
\hline \multicolumn{3}{|l|}{ Poultry house interest: interest rate (r) } \\
\hline (poultry hose value* $1 / 2 * 3 \%$ ) & 49.71 & 1.20 \\
\hline \multicolumn{3}{|l|}{ 16. Water bowl, manger, etc. } \\
\hline Depreciation $=($ value $*$ depreciation rate $\%)$ & 15.77 & 0.38 \\
\hline interest $=($ value $1 / 2 \% 5)$ & 13.15 & 0.32 \\
\hline 17. Total Fixed Costs (B) & 568.81 & 13.74 \\
\hline 19. Total Production Costs $(A+B)$ & 4138.83 & 100.00 \\
\hline Average Live Weight (kg/head) & 7.26 & \\
\hline Total Live Weight per farm (kg/farm) & 4630 & \\
\hline $1 \mathrm{~kg}$ live turkey cost $(\$ / \mathrm{kg})$ & 0.8939 & \\
\hline Sale price $(\$ / \mathrm{kg})$ & 1.4775 & \\
\hline Profit rate $\%$ & 65.284 & \\
\hline Gross production value ( $\$ /$ farm) & 6840.83 & \\
\hline Net income/year & 2702.00 & \\
\hline Gross Income/year & 3270.81 & \\
\hline
\end{tabular}

\section{CONCLUSION AND RECOMMENDATION}

As seen on Table 11 , Net income is $2702 \$$. It was determined that the adequate income for farms was 2740 \$ in 1984 in Turkey according to law 3083, Agricultural Reform on Regulations for Irrigated Land, published in Official Newspaper in December 1st, 1984 (Anonymous 1984). This value becomes $4400 \$$ when it is calculated as to 2002 Whole Price Index. Therefore, turkey breeding farms meet $61.41 \%$ of sufficient income from this production branch. Given important economic difficulties of farms stemming from economic crises in Turkey in recent years, revenues of farms obtained from turkey breeding can be regarded at important level. In addition, sheep and goats breeding and plant production are done on farms beside to turkey breeding. However, fulfilling of suggestions as 
fallow can contribute a lot to increase revenues obtained from extensive turkey breeding.

- Feed costs have the highest share in extensive turkey breeding (see Table 11). Therefore, decreasing cost of this input can play an important role to increase revenues. Given high share of arable field agriculture (Table 8) in plant production of turkey breeding farms, should farms provide their own feed within farm and/or from a feed unit by organization instead of buying outside will, enormously, decrease feed costs. In addition, opportunities of grazing at night should be searched during summer especially.

- The second place in production costs of turkey breeding belongs to chick purchases. As seen on Table 5, organizational level on farms examined is high. However, these organizations provide more services for plant production. Aim of these organizations should be decreasing chick purchase costs.

- Moreover, another important cost is medicine costs. These costs are, essentially, medical treatment costs. Breeders have insufficient information on herd health protection. However, literacy rate (Table 3) in families and visiting of household head to agricultural organizations are high (Table 5). Therefore, farmers should be conscious on herd administration and herd health protection. In addition, necessary services especially protective vaccine service by government should be made effectively.

- Young population rate on farms is quite high (Table 2). Therefore, if individuals except administrator work for turkey breeding, not only permanent and seasonal workmanship costs will decrease but also idle labor force will be used.

- Organizational level on farms examined is high (Table 5). Nonetheless, these organizations provide services, essentially, for plant production. Therefore, these organizations should be made work for establishment of poultry houses and decreasing costs at equipment purchase and effective marketing of turkeys. In addition, having organization on turkey breeding will, enormously, increase profitability.

\section{REFERENCES}

Aksoy, T. 1996 "Tekirdă̆ İli Üretici Koşullarında Besiye Alınan Bronz Hindilerde Kesim Sonuçlari", I. Ulusal Zootekni Bilim Kongresi, Antalya, 48-54

Aksoy, T., Ş. Aksoy ve Ç. Koçak 1996a "Otlatmaya Dayalı Hindi Besiciliğinin Durumu, Sorunlar, ve Çözüm Yollar”, Hayvancıllk '96 Ulusal Kongresi, İzmir, 446-454

Aksoy, Ş., T. Aksoy ve N. İşcan 1996b “Tekirdă̆ Ilindeki Otlatmaya Dayalı Hindi Besiciliğinde Maliyet Analizi", I. Ulusal Zootekni Bilim Kongresi, Antalya, 55-62

SIS 2001 Population Census in 2000, http:www.die.gov.tr

SIS 2002 Agricultural Census in 2001, http:www.die.gov.tr 